vitamin $\mathrm{D}$ metabolites after small bowel resection for Crohn's disease. Scand F Gastroenterol 1984; 19: 579-84

2 Eriksen EF, Mosekilde L, Melsen F. Effect of sodium fluoride, calcium, phosphate and vitamin $\mathrm{D}$, on trabecular bone balance and remodelling in osteoporosis. Bone 1985; 6: 381-9.

\section{Oesophageal strictures in dystrophic epidermolysis bullosa}

SIR, - Walton and Bennett in their progress report 'Skin and gullet' (Gut 1991; 32: 694-7) declare that diffuse oesophageal involvement in dystrophic epidermolysis bullosa is difficult to manage with a considerable risk of perforation. They recommend colonic interposition either by bypass or replacement of the strictured oesophageal segment. They base their recommendation on a report describing successful surgical oesophageal replacement in two patients.

I am concerned that patients with dystrophic epidermolysis bullosa complicated by oesophageal strictures may be subjected to major surgery when colleagues follow the recommendation of Walton and Bennett and thereby ignore an established non-operative treatment method. Balloon dilatation with balloons of predetermined size, placed in the oesophagus over a pathfinder string, combined with long term tube feeding is an effective and safe procedure.' Dilatation even of diffuse strictures in the thoracic oesophagus is no more difficult than in the cervical part. The avoidance of tangential shearing forces induced by bougienage and the use of balloon dilatators which produce vertical pressure reduce the risk of mucosal detachment. We have not seen oesophageal perforation with this method and no such complication has to my knowledge been reported with our method. Three of our original four patients treated with balloon dilatation and tube feeding nine or 10 years ago respectively have not experienced recurrence of tight oesophageal strictures. One patient developed severe dysphagia again four and five years after the original treatment ${ }^{2}$ and was retreated in $1987 .{ }^{23}$ with no further recurrence. Oesophageal surgery with its inherent risks has not been necessary in any of our patients.

G E FEURLE

Stadtkrankenhaus, Marktstr, 5450 Neuwied, Germany

1 Feurle GE, Weidauer H, Baldauf G, SchulteBraucks T, Anton-Lamprecht I. Management of oesophageal stenosis in recessive dystrophic epidermolysis bullosa. Gastroenterology 1984; 87: dermolysis

2 Weidauer H, Feurle GE, Baldauf G, AntonLamprecht I. Zur Therapie von
Ösophagusstenosen bei rezessiver Epidermolysis Ösophagusstenosen bei rezessiver Epidermolysis
bullosa dystrophica. Laryngorhinootologie 1985; bullosa dy $522-6$.

3 Seitz HK, Egerer G, Sina R, Baldauf G, Hartschuh $\mathrm{W}$, Anton-Lamprecht I, et al. Dilatationsbehandlung von Ösophagusstenosen bei jungen Patienten mit rezessiver Epidermolysis bullosa dystrophica. Z Gastroenterol 1990; 281: 157-9.

\section{Reply}

SIR, - We were most interested in Dr Feurle's success in treating epidermolysis bullosa oesophageal strictures by balloon dilatation and obviously this is a far more desirable approach than a surgical one - provided the stricture responds as well as his.

J R BENNETT Hull Royal Infirmary,

\section{Papillary cystic neoplasm of the pancreas}

SIR, - We were very interested to read of the description by Kingsnorth et al of two cases of this unusual primary pancreatic tumour (Gut $1992 ; 33: 421-3)$. We have also recently seen a case of this rare neoplasm which presented in a 27 year old woman as an abdominal mass approximately eight to 10 weeks post partum. Computed tomography of the abdomen revealed a well defined non-homogeneous mass arising in the body and tail of the pancreas. The tumour was encapsulated, measuring $25 \times 17 \times 13 \mathrm{~cm}$, and partly necrotic, showing solid and papillary areas. The tumour cells showed generalised positive immunohistochemical reactivity with neuron specific enolase, and focal immunoreactivity for insulin and glucagon. The tumour cells showed no evidence of PGP 9.5, somatostatin, or gastrin immunoreactivity. Electron microscopy showed scattered dense core neurosecretory granules and intercellular junctional complexes (desmosomes).

The immunohistochemical pathological findings seen in papillary cystic tumours of the pancreas are not always characteristic; often being quite variable. ${ }^{12}$ Papillary cystic neoplasms of the exocrine pancreas may sometimes show neuroendocrine features as seen in primary pancreatic islet cell tumours. The immunohistochemical findings are therefore not always characteristic and a final pathological diagnosis rests on knowledge of the site and size of the neoplasm, the young age and female sex of the patient, and the microscopic appearance of the tumour. A failure to appreciate the variable immunohistochemical characteristics of papillary cystic neoplasms of the exocrine pancreas may lead to errors in the interpretation of the pathology of these rare pancreatic tumours by causing potential diagnostic confusion with primary pancreatic islet cell tumours. J S DAWSON A R MANHIRE City Hospital, Hucknall Road, Nottingham NG5 IPB

1 Miettinen M, Partanen S, Fraki O, Kivilaakso E. Papillary cystic tumor of the pancreas. An analysis of cellular differentiation by electron microscopy and immunohistochemistry. $A m \mathcal{F}$ Surg Pathol 1987; 11: 855-65.

2 Bogomeletz WV. Cystic tumours of the pancreas. In: Anthony PP, MacSween RNM, eds. Recent advances in histopathology. 15. London: Churchill advances in histopathology. 15.

\section{NOTES}

\section{Gastrointestinal Motility}

The Sixth European Symposium on Gastrointestinal Motility will be held from 19-21
November 1992 in Barcelona. Further information from Unicongress, Calvet, 55 (403a) 08021 Barcelona, Spain. Tel: 34341403 22; Fax: 3434140251.

\section{Digestive Surgery}

The European Workshop on Digestive Surgery will be held on 5-6 November 1992 in Brussels. Further details from Conference Services, Avenue de l'Observatoire 3, Box 17, B-1180 Brussels, Belgium. Tel: 322375 1648; Fax: 32 23753299.

\section{European Pancreatic Club}

The 24th Annual Meeting will be held in Ulm Germany from 11-14 October 1992. Further details from Marga Wild, Department of General Surgery, University of Ulm, Steinhoevelstr 9, D-7900 Ulm, Germany. Tel: 731 502 7200/1; Fax: 7315027209.

\section{Clinical Nutrition}

The Leeds course in Clinical Nutrition will be held from 15-18 September 1992. Further information from Mrs Hilary L Helme, Department of Continuing Professiona Education, Continuing Education Building, Springfield Mount, Leeds LS2 9NG. Tel: 0532 333233.

\section{American Gastroenterological Association} 1992 Fall Postgraduate Course

The 1992 Postgraduate Course will be held from 17-19 September, 1992 in San Francisco, California. Further information from SLACK Incorporated, 6900 Grove Road, Thorofare NJ 08086-9447, USA. Tel: 6098481000.

\section{Sir Francis Avery Jones BSG Research Award 1993}

Applications are invited by the Education Committee of the British Society of Gastroenterology who will recommend to Council the recipient of the 1993 Award. Applications (15 copies) should include:

(1) A manuscript (2 A4 pages only) describing the work conducted.

(2) A bibliography of relevant persona publications.

(3) An outline of the proposed content of the lecture, including title.

(4) A written statement confirming that all or a substantial part of the work has been personally conducted in the United Kingdom or Eire.

The award consists of a medal and a $£ 100$ prize. Entrants must be 40 years or less on 31 December 1993 but need not be a member of the BSG. The recipient will be required to deliver a 40 minute lecture at the Spring Meeting of the Society in 1993. Applications (15 copies) should be made to: The Honorary Secretary, BSG, 3 St Andrew's Place, London NW1 4LB by 1 December 1992. 